\title{
Role of autophagy in K-RAS- and B-RAF-driven lung cancers
}

\author{
Eileen White ${ }^{1,2}$ \\ From Metabolism, Diet and Disease 2014: Cancer and metabolism \\ Washington DC, USA. 28-30 May 2014
}

Autophagy degrades and recycles proteins and organelles to support metabolism and survival starvation. Oncogenic RAS upregulates autophagy required for mitochondrial function, stress survival, and engrafted tumor growth. We deleted an essential autophagy gene, autophagy-related-7 (Atg7), concurrently with Kras ${ }^{G 12 D}$ activation with or without intact Trp53 in two mouse models for non-small-cell lung cancer (NSCLC). In both models, Atg7 deficiency caused tumor cells to accumulate dysfunctional mitochondria, and acquire metabolic, growth and survival defects associated with reduction in tumor burden. Importantly, $\operatorname{Atg} 7$ deficiency altered the fate of $\mathrm{Kras}^{G 12 D}$-induced carcinomas to that of oncocytomas, rare, predominantly benign tumors characterized by the accumulation of defective mitochondria. Surprisingly, lipid accumulation was observed in Atg7-deficient tumors only when Trp53 was deleted. Atg7-deficient tumor-derived cell lines (TDCLs) had compromised starvation survival and formed lipidic cysts instead of tumors, suggesting defective utilization of lipid stores. Atg7 deficiency reduced fatty acid oxidation (FAO) and increased sensitivity to FAO inhibition, indicating that with $\operatorname{Trp} 53$ loss, RAS-driven tumors require autophagy for mitochondrial function and lipid catabolism. Thus, autophagy is required for carcinoma fate, and cancers require autophagy for distinct roles in metabolism that are oncogene- and tumor suppressor gene-specific. To test the role of autophagy in oncogenic signaling pathways downstream of RAS, $\operatorname{Atg} 7$ was deleted in a mouse model of $B R A F^{V 600 E}$-induced lung cancer in the presence or absence of the tumor suppressor Trp53. Atg7 deletion initially induced oxidative stress and accelerated tumor cell proliferation in a manner indistinguishable from $\mathrm{Nrf} 2$ ablation.

Compound deletion of $\operatorname{Atg} 7$ and $N r f 2$ had no additive effect suggesting that both genes modulate tumorigenesis

${ }^{1}$ Rutgers Cancer Institute of New Jersey, New Brunswick, NJ 08903, USA Full list of author information is available at the end of the article by regulating oxidative stress, revealing a potential mechanism of autophagy-mediated tumor suppression. At later stages of tumorigenesis, $A \operatorname{tg} 7$ deficiency resulted in an accumulation of defective mitochondria, proliferative defects, reduced tumor burden, conversion of adenomas and adenocarcinomas to oncocytomas, and increased mouse lifespan. Autophagy-defective tumor-derived cell lines were defective in their ability to respire, survive starvation and were glutamine-dependent, suggesting that autophagy-supplied substrates from protein degradation sustains $\mathrm{Braf}^{V 600 E}$-tumor growth and metabolism.

\section{Authors' details}

${ }^{1}$ Rutgers Cancer Institute of New Jersey, New Brunswick, NJ 08903, USA. ${ }^{2}$ Department of Molecular Biology and Biochemistry, Rutgers University, Piscataway, NJ, 08854, USA.

Published: 28 May 2014

doi:10.1186/2049-3002-2-S1-011

Cite this article as: White: Role of autophagy in K-RAS- and B-RAFdriven lung cancers. Cancer \& Metabolism 2014 2(Suppl 1):O11.

Submit your next manuscript to BioMed Central and take full advantage of:

- Convenient online submission

- Thorough peer review

- No space constraints or color figure charges

- Immediate publication on acceptance

- Inclusion in PubMed, CAS, Scopus and Google Scholar

- Research which is freely available for redistribution
C Biomed Central

(c) 2014 White; licensee BioMed Central Ltd. This is an Open Access article distributed under the terms of the Creative Commons Attribution License (http://creativecommons.org/licenses/by/4.0), which permits unrestricted use, distribution, and reproduction in any medium, provided the original work is properly cited. The Creative Commons Public Domain Dedication waiver (http:// creativecommons.org/publicdomain/zero/1.0/) applies to the data made available in this article, unless otherwise stated. 